\title{
Gruppeterapeutiske erfaringer fra sorgarbeid
}

\author{
Ved A nne Berit H ovind og Per A rne H agen
}

\begin{abstract}
Siden januar 1999 har det i Grorud bydel i Oslo vaert drevet samtalegruppe for pårørende etter selvmord og andre uventede dødsfall. Målsettingen for gruppen er å vaere et sted huor deltakerne kan møte andre som har mistet noen i selvmord, og få hjelp til å bearbeide noe av det som er vanskelig. Det kan gi hjelp til å leve videre.
\end{abstract}

\section{Sorggruppe-tilbudet i Grorud bydel}

Sokneprest Sonja Fauske i Rødtvet kirke tok initiativ til at det ble startet en sorggruppe for pårørende etter selvmord. $\mathrm{H}$ un hadde savnet å ha et slikt nettverkstilbud å vise til hvis det skjedde selvmord i menigheten. I januar 1999 startet prosjektleder i psykiatri A nne Berit H ovind og psykiatrisk sykepleier Torill H ellem gruppen. Høsten 1999 ønsket $\mathrm{H}$ ellem å slutte, og psykiatrisk sykepleier Per A rne $\mathrm{H}$ agen overtok etter henne. Siden januar d.å. har gruppen holdt til i lokaler på dagavdelingen på G rorud DPS.

Siden januar 1999 har gruppelederne ledet flere grupper. G ruppen har hatt fem - seks medlemmer av gangen. Sorggruppen har møttes annenhver tirsdag, halvannen time over et halvt år. Vår erfaring er at korttidsgrupper fungerer best. Da er gruppen mest stabil og har et fast antall medlemmer som tar opp en rekke forskjellige temaer.

\section{Hvordan får vi henvisninger?}

Tilbudet om å bli med i sorggruppen skjer på flere måter: dels etter henvisning fra førstelinjetjenesten, G rorud DPS eller prestene i G rorud bydel. Vi har laget en brosjyre: "Samtal egruppe for pårøren de etter selvmord og plutselige dødsfall", som vi deler ut til interesserte. Den samme brosjyren ligger på Internett, på vev-sidene til Seksjon for selvmordsforskning og -forebygging. Flere har kontaktet oss etter å ha lest den.

De fleste av deltakerne har kommet til sorggruppen i månedene like etter dødsfallet, mens et par har kommet etter hhv. 7 og 13 år. D ette skjedde etter at de var anbefalt gruppen av diakon eller prest.

\section{Gruppens sammensetting}

$G$ ruppelederne har bestemt at gruppen skal være en gruppe for pårøren de etter selvmord og andre uventede dødsfall. En sorggruppe med bare deltakere som har mistet sine kjære i selvmord, kan etter vår erfaring bli en meget dramatisk gruppe, der deltakerne kan føle det svært belastende å høre så mange tragiske historier. For å unngå dette og for å skape balanse i gruppen har vi tatt inn personer som har opplevd å miste sine p.g.a. sykdom eller ulykker. Det kan synes som om de sistnevnte har lettere for å slippe fri gråten i forbindel se med sorgen. De som har opplevd selvmord, kan ha en tendens til først å gi uttrykk for sitt sinne i gruppen. Ved å se andre reaksjonsmåter i forbindelse med sorg kan den enkelte få hjelp til forstå egne reaksjoner, kanskje endre dem og etter hvert tilpasse seg den nye livssituasjonen.

\section{Inntakssamtale}

Vi har intervju med samtlige av deltakerne på forhånd, for bl.a. om mulig å finne ut om gruppen vår er et egnet tilbud for dem, og for å finne ut hvor motiverte de er for å delta. Tanken vår har vært å sette sammen personer som kan utgjøre "et godt team", dvs. mennesker i samme alder, men med forskjellige opplevelser. Vi har prøvd å ta inn flere med lik problematikk, f.eks. noen som har mistet sin mann eller sin sønn. I intervjuet gjennomgår vi "kjørereglene" for gruppen, for å forberede deltakeren.

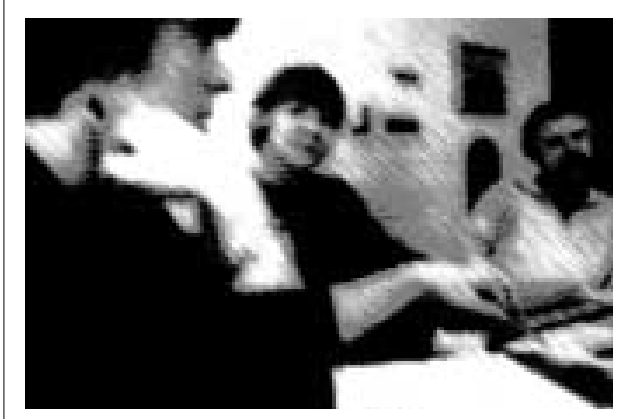

\section{Gruppekontrakt}

For at utbyttet av å delta i gruppen skal bli størst mulig, har vi noen regler når det gjelder forpliktelse, ansvar i gruppen og den enkeltes ansvar utenfor gruppemøtene. Tanken bak er at en gruppekontrakt er en god ramme for å øke samholdet i gruppen. Den enkelte forplikter seg til å delta på alle gruppemøtene så langt det er mulig, med mindre man har en god grunn til å være borte, f.eks. sykdom. $\mathrm{H}$ vis noen har tanker om å slutte, bør de fortelle det i gruppen. Det er viktig å være så åpen som mulig og dele med gruppen det som opptar tankene og hva man selv føler. Taushetsplikt er viktig for at enhver skal kunne føle seg trygg til å dele personlige erfaringer med de andre gruppedeltakerne. Ingen skal bringe videre til andre informasjon som kan identifisere en annen gruppedeltaker. Det man eventuelt kan fortelle om, er hva man selv har sagt $\mathrm{i}$ gruppen om seg selv.

\section{Hvilken metode bruker gruppelederne?}

I gruppen fokuserer vi på her og nå. Er f.eks. en person borte, leder vi oppmerksomheten mot den tomme stolen. "H va slags tanker gjør de andre seg om at N .N er borte?" Hensikten er få frem fantasier om fraværet. Da kan det eksempelvis komme frem tanker om at det en deltaker sa til N .N , har vært sårende eller støtende. Da N .N kom tilbake, fikk vi høre at telefonen hadde vært frakoblet og at hun derfor ikke kunne gi beskjed til oss. En slik metafor "være frakoblet" er ypperlig til å bruke videre i gruppemøtet. $G$ ruppelederen kommenterte: “D et å være frakoblet er noe som også til tider skjer i denne gruppen. Det skjer ved at man trekker seg tilbake, blir taus og unnlater å gi respons på det en annen deltaker sier. N ettopp ved at man deler det man har på hjertet, kan man bli tilkoblet igjen og kontakten er til stede." Det er også viktig å fokusere på likhetspunkter mellom deltakerne for derved å hindre negative tanker om gruppen og deltakerne. Det skjer ved at gruppelederen f.eks. sier: "D et du forteller, er ikke er så veldig ulikt det $X$. fortalte." Vi opp- 
muntrer deltakerne til å snakke om alt de er opptatt av. For å knytte det noen har fortalt til det som har felles betydning, hender det at vi spør: "H ar flere hatt en lignende erfaring?" Vi stiller spørsmål rundt tema og prøver å holde deltakerne litt der, for slik å vise at vi følger den enkelte, uten å øve press på den sørgende til å snakke om problemene. For at enkelte utsagn skal bli mer forståelige for alle, spør vi om flere opplysninger.

Vi legger vekt på å gi positive tilbakemeldinger til deltakerne.

V år hensikt er å være støtten de gruppeledere som oppmuntrer, gir veiledning, hjelper til med problemløsning og kommer med meninger, av og til noe om verdisyn og noen personlige opplysninger. Bruk av en støtten de tilnærming i sorggrupper baserer seg på tanken om at en reduksjon av symptomer og bedring av livskvalitet skjer gjennom uttalt støtte (McCallum et al. 1998).

\section{Hvilke temaer taes opp i sorggruppen?}

Startmøtene er ofte noe famlende. En naturlig usikkerhet og fremmedfølelse preger de første møtene. D et å fortelle sin historie er en begynnelse. Etter hvert som deltakerne blir tryggere, går praten mer av seg selv. Temaene er fra det praktisk-opplevelsesmessige: besøket på den avdødes grav. H va står på gravstøtten? $\mathrm{H}$ vordan er beliggenheten? $\mathrm{H}$ vordan føles det å gå på besøk til den kjæres grav i ettertid? H vordan var begravel sen? H vordan vil du beskrive pyntingen, sangen, møtet med presten? Det er atskillig praktisk som må ordnes ved en begravelse. Det viser seg ofte at dette er tema som øøsner samtalen. Samtalen blir engasjerende og til dels livlig. A tmosfæren blir mer fortrolig og varm.

Det er også slik at de som er igjen etter brå død og selvmord, føler at de sitter igjen med mange usagte ting. 0 rd som skulle vært sagt, men som det al tså ikke ble noe av. Skyldfølelsen kan være vond å bære. Det kan være et sterkt behov for å eksponere sitt indre for den som døde. "Jeg snakker med ham på gravlunden, jeg, "

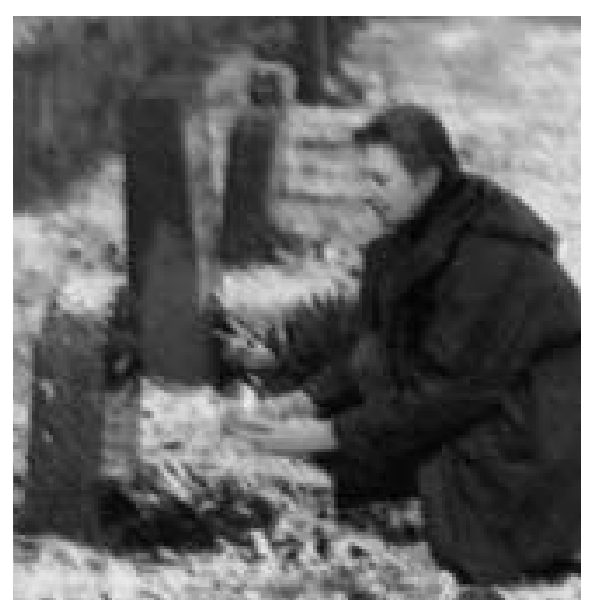

sier en. H un snakker med sin kjære. Det som ikke ble sagt mens den kjære levde, sies nå. Det gir lindring i sorgen og smerten.

"H va giøres med den avdødes saker? KIær, personlige ting, - rydder dere det bort?" Spørsmålet tar bevisst tak i saker på det praktiske planet og innbyr til personlige svar. Svarene kommer. G ruppemedlemmene gir hverandre råd, og de forteller hverandre om hva som føles vanskelig. De kjære minnene oppleves som et faktisk nærvær av den døde. $\mathrm{H}$ an er her. $\mathrm{H}$ un bor her fremdeles. KIærne i skapet, sysakene, pipen i askebegeret. Den kjære er nær. Tapet, avstan den forkortes. $M$ ange sier at å fjerne eiendel ene etter den avdøde er noe av det mest vonde og smertefulle.

D et er ikke så vanskelig å snakke om hva som førte til dødsfallet; om sykdommen, om ulykken og om hvordan det vonde hendte.

Et tema som naturlig kommer opp på gruppemøtene, er spørsmålet: "H vordan kan jeg noen gang bli glad igjen?" "Er det noen vei tilbake til livet igjen? Kan jeg finne tilbake til meg selv uten å ha bare tunge minner?" A rbeid med slike spørsmål nærmer seg individuell terapeutisk tilnærming. "Jeg er akkurat som i et vakuum, utenfor meg selv." "H va kunne jeg ha gjort annerledes, jeg ante jo ingen ting!" Det er skyldfølelsens skygger som kan dempe livsmot og vilje. En deltaker som sliter med dette, bør få tilbud om samtaleterapi, evt. sjelesorg hos en prest. G ruppens medlemmer har også mange praktiske råd å gi hverandre: råd mot søvnløshet, om kosthold, daglige rutiner, fysisk trening eller om å ta initiativ til å treffe en god venn eller en venninne. $D$ et å føre dagbok blir nevnt som en hjelp og støtte til å komme igjennom hverdagen.

På et senere gruppemøte blir håpet for fremtiden nevnt. G ruppens vei videre med slike spørsmål er spennende og utfordrende. "Er det noen mening i det som oppleves meningsløst?" For selv om gruppen utvikler seg etter en "self-governing"modell, vil det kreve modenhet og en god empatisk innlevel se av gruppelederne når sentrale verdispørsmål tas opp.

$\mathrm{N}$ år sorggruppen, som er en korttidsgruppe, nærmer seg sluttfasen, sier gruppelederne i fra når det er to gruppemøter igjen. På siste gruppemøte legger vi vekt på å gi positiv feedback til gruppen som helhet og søker å unngå individuelle tilbakemeldinger.

\section{Litteraturhenvisning}

M CC allum M, Piper W E, Joyce A S: "M anual for time-limited, short-term, supportive group therapy for patients experiencing pathological bereavement."

Psychotherapy Research C entre, Department of Psychiatry, Edmonton, A lberta, 1998

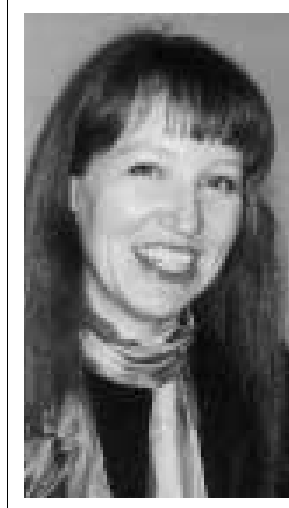

A nne Berit Hovind er prest og prosjektleder $\mathrm{i}$ psykiatri i G rorud bydel i O slo. H un er tilknyttet A mmerud gård som er et aktivitetssenter for personer med psykiske lidelser. $\mathrm{H}$ un har flere års praksis som sykehusprest, og har ledet sorggrupper bl.a. ved R adiumhospitalet. A nne Berit H ovind tar utdanning i gruppepsykoterapi ved The Institute of $G$ roup A nalysis, Storbritannia.

Per A rne $\mathrm{H}$ agen er psykiatrisk sykepleier ved G rorud DPS. Han har i mange år vært sykepl eier ved Lovisenberg sykehus, har arbeidet i alderspsykiatrien og er nå ansatt som avdelingssykepleier på dagavdelingen ved $\mathrm{G}$ rorud DPS. $\mathrm{H}$ an er for tiden $\mathrm{i}$ gang med veiledningsutdanning for sykepleiere.

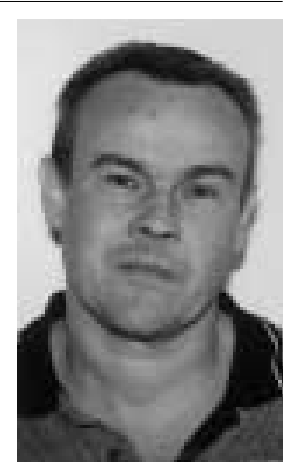

